Fedorova : Sb. Tr. Tsentr. Nauchn.-Issled. Inst. Chernai Met., 1963, 83. 525) A. B. Shaevich, et al. : Zavodsk. Lab., 30, 1343 ('64). 526) M. Chaput, J. N. Savarit : Anal. Chim. Acta, 31, 563 ('64). 527) S. B. Shubina, N. I. Zhorova : Zavodsk. Lab., 30, 1350 ('64). 528) M. J. Romand, M. R. Berneron : Publ. Group Avan. Methodes Spectrog., 1963, 327. 529) R. Berneron: Centre Document Sidérurg. Circ. Inform. Tech., 20, 743('63). 530) V. A. Fassel, J. W. Goetzinger: Spectrochim. Acta, 21, 289 ('65).

531) 古矢元佑 : 分化, 12,923 ('63). 532) V. I. Gladushchak, E. Ya. Shreider : Zavodsk. Lab.,
30, 47 ('64). 533) O. P. Bochkova, N. V. Chernysheva : Gaz. Prom., 9, 46 ('64). 534) Z. L. Grove, et al. : Welding J., 43, 282 ('64). 535) A. G. Zhiglinckii, A. N. Zaidel, A. A. Petrov : Zavodsk. Lab., 29, 550 ('63). 536) L. Gabla, J. Mokwa, H. Niewodniczanski : Acta Geophys. Polon., 11, 147 ('63). 537) A. G. Zhiglinskii, A. S. Kochemirovskii : Vestn. Leningr. Univ., 18 (16), Ser. Fiz., i Khim., No. 3, 62 ('63). 538) G. S. Lazeeva, A. A. Petrov, V. V. Fedorov: ibid., 56 ('63). 539) H. Dunken, W. Mikkelit, G. Haucke : Z. Chem., 3, 477 ('63).

\title{
8 原子吸光分析および炎光分析
}

\author{
武内 次夫 ·鈴木 正巴*
}

1963 年および 1964 年に発表された文献のうち, その おもなものを取り上げ，この分野の進歩の概要を説明す る.

\section{$8 \cdot 1$ 原子吸光分析}

$8 \cdot 1 \cdot 1$ 総説および著 原子吸光分析に関する総説 は数多く, 原理, 装置, 分析法の問題点などを解説した

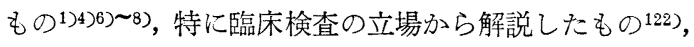
進歩の概要を説明したもの 233 , 炎光分析と比較して解説 したもの129)などがある．単行本としては「原子吸光分 光分析法」が刊行され ${ }^{9)}$ ，また分光分析法の 1 項目とし て原子吸光分析法を解説したもの10)る出版された. 国際

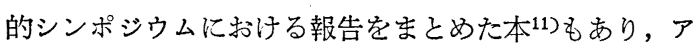
メリカにおける分光分析シンポジウムの報告を集めた

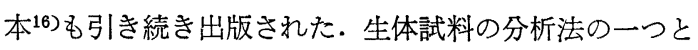
して原子吸光分析を説明した本 ${ }^{21) も あ る . ~}$

$8 \cdot 1 \cdot 2$ 装置 市販の装置で核来の分光光度計に原 子吸光付属装置を取り付けたもののほかに専用器も多数 開発されている． 単光束型が多いが, Perkin-Elmer 303 型は複光束型でその詳細も報告されている22). また, 既存の分光光度計を改造して分子による吸収測定用にも 原子吸光分析用にもなるようにした報告 ${ }^{24)}$, 光源のユラ ギを補償して検出限度を下げるように複光束型原子吸光 分光光度計を改良した報告23)もある. 光源からの光をチ

* 名古屋大学工学部合成化学科 (名古屋市千種区不 老町)
ョッパーで 75 サイクルのク形波に变調し, その信号を 非同期方式の Twin-T 回路を応用した狭帯域増幅器て 増幅する単光束型装置が試作された25)。バーナーについ ては魚尾状バーナー23)，炎光分析および原子吸光分析用 の噴霧バーナー29)を試作した研究がある.

$8 \cdot 1 \cdot 3$ 光源原子吸光分析では光源は装置の重要ふ 部分の一つである. 光源には中空陰極ランプを用いるの が普通であるが，ランプの性能は分析法の感度，精度な どに影響するところが大きい。一般には封じ込み型の中 空㓌極ランプが用いられるが, 組み立て型のランプは陰 極の交換が容易で, 安定度も封じ込み型のものに劣らな い17. しかし, 組み立て型のものはガス調節が必要で, 操作にかなりの熟練を要する欠点がある. 中空陰極ラン プの陰極材料およびその構造はランプの寿命あるいはそ れからでる共鳴線の強度に影響する．マグネシウム中空 陰極ランプでは純マグネシウムで陰極をつくるよりもマ グネシウムーアルミニウム合金を用いると共鳴線が強く, 自己吸収が小さくて寿命が長いという8). ランプの封入 ガスも測定に影響する場合がある.アルゴン封入ランプ ではアルゴン $3577 \mathrm{~A}$ 線がクロム $3579 \mathrm{~A}$ 線を妨害す る58).したがって, ランプの封入ガスを変えるか, ある いはこの場合にはクロム 3593A 線を用い, スリット幅 を狭くして測定する.多元素混合型中空陰極ランプも使 用されているが，この種のランプ注ある程度の制約をう ける8.

吸光線の吸光に対する光源光の線幅の影響が理論的に 
研究され, 光源の線幅が吸光線の線幅より狭い範囲では 測定された吸光度は理論的な吸光度に比例し, 吸光線の 線幅には無関係であることが示された40). 中空陰極ラン プの放電電流を増加させるとドップラー効果による線幅 が大きくなり，ランプ中の基底状態原子の密度が増加し 自己吸収が大きくなるが, 吸光に与える影響は自己吸収 が大きいタ).

光源として連続スペクトル光源を用いる試み13)31)もあ り，また炎を光源としてユーロピウム，ツリウム，イッ テルビウムの吸光スペクトルが検討された 27). この場合 にはほぼ化学量論的組成の酸水素炎あるいは酸素-アセ チレン炎を用いる。

$8 \cdot 1.4$ 試料の原子化 試料を原子化する方法は炎を 用いるのが一般的であり，広く用いられている. 試料の 噴霧方法に濆霧室を経て微粒子化されバーナーに導か れる方式ふよび噴霧バーナーを用いて試料を直接炎中に 導入する方式がある. いずれの場合にも炎中の原子密度 は一様でないため測定位置が重要になる。これはアル ミニウムのような 元素では顕著で46)47)，その位置によ っては測定が不可能になる場合もある. そのためバーナ 一の位置を簡易に調節する考案 26 もある. 炎中で酸化物 を生成しやすい元素では燃料の割合を多くした炎（fuel rich flame)を用いると遊離原子の濃度が増大する ${ }^{31) 32) . ~}$ バナジウム, チタン, ニオブ, スカンジウム, イットリ ウム, レニウム, 希土類元素もこのような炎を用いると 強い吸光を示すようになる.この場合に炎のバック・グ ラウンド信号を機器的に減少させる研究もある35). 炎の 種類も測定に影響する.ルビジウムの測定で, 空気ーア セチレン炎を窒素でうすめて用いるとセシウムおよびカ リウムの干渉が著しくなり, 炭酸ガスー空気ーアセチレン 炎でもセシウムの干渉がある79). この場合に注高温炎が 適当である、噴霧バーナーを用いた場合の炎中の原子密 度は噴霧室を備えたものに比べてかなり異なった分布を 示す. 炎ノイズを減少させ, 検出限度を高めるために新 しい噴霧バーナーが考案された ${ }^{29)}$.

原子吸光分析では光路における基底状態原子の数が多 いほど吸光が大きくなる，そのため，噴霧バーナーから の炎を長い管の一端から導入する長吸収光路方式が研究 された ${ }^{30} 17$ ). 光源からの光はこの管の中を通りその吸収 が測定されるのであるから感度が著しく増大する．この 方式では試料溶液中に存在する溶質による吸収がある が，試料をうすめて用いるとこの影響を避けうるとい う17). 感度を上げるため光源の光を炎中に折り返し通す 方式も用いられる32). Jarrell-Ash 社の装置は折り返し 方式を採用している.
炎中における金属原子の生成機構についても考察が行

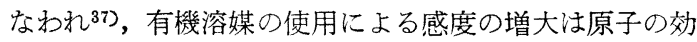
果的な生成と炎の温度の上昇に基づくものと説明され た. 有機溶媒は燃えやすく，また無機塩からよりも有機 化合物からのほうが原子が離れやすいため，金属が有機 金属化合物あるいは錯体の形で有機溶媒中に存在すると 炎中の金属原子のポピュレーションが増大し吸光が増す のであるという．有機溶媒を用いる場合には炎中の測 定位置の選択が 重要で, 空気ープロパン炎を用い, ガソ リン中の鉛を定量する場合には炎の下部が 吸光が大き (38).

炎中の原子蒸気の線プロフィルについて検討され，炎 の種類による吸光強度の相違は主として炎が原子蒸気を つくる能力と吸光の中心の波長および線プロフィルによ るものと説明された8).

炎を用いないで中空陰極ランプ型の装置を用いて試料 を原子化する方法も引き続き研究され ${ }^{399}$ ，同位体分析に 応用された52)53). 試料を黑鉛の炉に入れ，アルゴン気中 でアークによって気化される方法はソ連で用いられてい る64). 蓄電器放電定用いる原子化の試みもあるが42), 実 用の点では問題がある・レーザーの応用は将来の課題で ある・

$8 \cdot 1 \cdot 5$ 干渉 原子吸光分析の特長の一つは干渉の少 ないことである。しかし，実際にはいるいろの干渉現象 が報告されている、鉛 $2833 \mathrm{~A}$ 線は $\mathrm{OH}$ によって吸収 をうける14)37)。このような分子帯スペクトルによる干涉 は空気一石炭ガス炎, 酸水素炎のいずれにおいても認め られるが，マグネシウム $2852 \mathrm{~A}$ 湿影をうけない。

化学的干渉については多数の報告がある. ストロンチ ウムはアルミニウムの共存で影響を受け吸光が減少する が，リン酸は逆に吸光を増大させる(1).アルミニウムの 干渉法ランタンの添加で抑制される．マグネシウムに対 するアルミニウムの干渉はオキシンを添加して噴霧する と軽減できる55). クロムに対するモリブデン，タングス テンなどの干涉は炎の型および炎中の測定位置で異な る58).

化学的干渉除去の方法としてイオン交換樹脂が用いら れることもあるが，原子吸光分析のためのイオン交換力 ラムが考案された ${ }^{45}$. 溶媒抽出法も広く利用される.ア ルミニウムを 4-メチル-2-ペンタノンで抽出すれば他の 陽イオンおよび陰イオンの干渉がなくなる46)47)。溶媒抽 出法の併用は干涉元素の除去だけでなく, 目的元素の濃 縮手段ともなり，有機溶媒効果ともあいまって微量成分 の定量に効果が大きい， パラジウム51)，銀49)，ニッケ ル62), 金45)などの定量に応用された。 
8.1.6 感度, 精度および正確さ 原子吸光分析法の 感度注用いる装置および元素によって異なるるのであ る. 複光束型装置では読みの安定性がよく, 目盛拡大装 置を使用することによって同一吸収光路で少なくとも感 度を 5 倍にすることができる22，また，光路を長くして 亜鉛, カドミウム, マグネシウム, 銅, ニッケルおよびュ バルトを $0.4 〜 16 \mathrm{ppb}$ まで検出した報告30) もある。原 子吸光分析の最小検知濃度と実験条件との関係式を導い た研究が報告された ${ }^{41)}$. ベックマン全消費型酸素-アセ チレンバーナーを予備混合方式に改良し感度を 10 倍に 上げた報告もある29)。これは改良バーナーの安定性が高 くなったことに基因する、ランプの封入ガスによるスペ クトル線が目的スペクトル線と重なる場合に法感度が下 がる.クロムの場合について検討されている58).

原子吸光分析法の正確さを取り扱ったものとしては， 亜鉛44)，血清中のマグネシウム8) 関する報告がある.

吸光度と濃度の間に $E=K C^{n}$ ( $n$ 注直線の傾斜) の関 係がある場合に，濃度を变えて $n=\log \left(E_{1} / E_{2}\right) / \log \left(C_{1} /\right.$ $\left.C_{2}\right)$ を求め $n$ および $d n / n$ によって測定の精度を判定 しうることを示した研究がある43).

$8 \cdot 1 \cdot 7$ 応用 原子吸光分析の応用についての研究注 少なくない，生化学領域で浽脳せき娟迹液中のマグネシウ ムおよびカルシウムの定量を検討した報告 ${ }^{77}$, 血清およ び尿中のマグネシウムの定量について検討し，血清で注 除たえ白を行ない，尿では単なる希釈で十分満足な結果

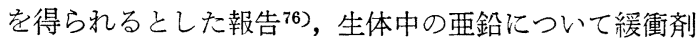
を添加して定量した報告 ${ }^{74)}$ ，血清中のカルシウム関す る報告 ${ }^{75)}$, 血清中のマグネシウム定量の正確さを炎光分 析と比較研究した報告80)などがある。

農学領域では農産物中のルビジウム ${ }^{79)}$, 魚粉中の鉛 ${ }^{67}$ などが定量された。

高分子工業ではポり塭化ビニルを溶剤に溶かし，ての まま噴霧して亜鉛，鉛，カルシウムを定量した報告73)， ポリプロピレンを灭化し，カルシウムをストロンチウム とともにシュウ酸塩として共沈分離したのち溶液に変え て噴霧定量した報告72)がある．後者の報告ではストロン チウムが共沈剤になるとともに，わずか残留する恐れの あるチタン，アルそニウム，リンなどの干渉抑制戍とし ても㗢く.

原子吸光分析法はケイ酸塩試料の分析にも好適であ る. 石灰石中のナトリウムの定量についてカルシウムイ オンおよび塩素イオンの影響が検討された ${ }^{68)}$ 。セメント 中のナトリウム, カリウム, マグネシウム, マンガン およびカルシウムの定量が検討され，前 3 元素について は検量線法と標準添加法の結果が比較された69).スラッ
グ中のカルシウムおよびマグネシウム70), 岩石中の銅お よび覀鉛の定量 ${ }^{67)}$ ，さらに石炭灰中のストロンチウムの 定量 ${ }^{11}$ が報告されている。

治金領域における応用も多い。アルミニウム中の 銀 ${ }^{54)}$, 鉄鋼中の銅68), コバルト57)，クロム ${ }^{58) ， マ ク ゙ ネ シ ウ ~}$ $\Delta^{70)}$, マンガン ${ }^{60) 61)}$, ニッケル62(63) は特別の処理をしない で定量することができる。しかし，多量の母体金属が多 少影響するので検量線は実際の試料溶液と同一組成の溶 液を用いて調製する必要がある。この不便を圭くすた め，鉄をメチルイソブチルケトンで抽出除去してマグネ シウムを定量した報告59)，あるいは同椂に鉄を除去して ニッケルを定量した報告62がある．さらに，少量のニッ ケルを定量するためこれを錯体として抽出し定量する方 法62)も報告された．アルミニウム中のマグネシウムを定 量する場合にはアルミニウムの干渉が現われるが，オキ シンを添加すると干渉が抑制されるという55)、タングス テンカーバイド中の鉄の定量65)，炎を用いないで黒鉛忓 中でアークを用いて原子化し，金属合金中のアルミニウ ムを定量した研究64もある。

水中のマグネシウム，カルシウム，カリウム，ナトリ ウム，銅および鉄の定量 ${ }^{123)}$, halo phosphate phosphorous 中のナトリウムの定量 ${ }^{66)}$ 報告された.

同位元素の分析は原子吸光分析法の重要な応用面の一 つである。 ウラン同位体組成 ${ }^{52)},{ }^{7} \mathrm{Li} /{ }^{6} \mathrm{Li}^{533)}$ が測定され た、いずれも中空陰極ランプ型の装置を用いるのである が，光源に用いるのと異なり高電流で操作して原子化す る.

8.1 .8 原子ケイ光分析 炎中の原子が適当周波数の ふく射線を吸収して励起する場合にケイ光を発する。こ のケイ光ふく射線は吸光原子に特有なもので, その強度 を測定して定量を行なうことができる．これ洼発光法の 一種と考えられ，原子ケイ光分析法 (atomic ffuorescence spectrometry）と呼ばれ，その理論的考察なら びに原子吸光分析, 炎光分析との比較についての研究 ${ }^{81)}$ が報告された．原子ケイ光分析の装置は原子吸光分析の 装置に類似し，炎からのケイ光が光源からの光之直角な 方向で観測される. 試料がケイ光ふく射線と同じ周波数 の熱的ふく射線をだす場合には光源の光を変調する必要 がある．この方法は水溶液中の亜鉛，カドミウムおよび 水銀の分析に用いられたが82), 紫外領域に共鳴線を有す る元素の定量に適当である.

\section{2 炎光 分 析}

$8 \cdot 2 \cdot 1$ 総説および著吾 総説としては原子吸光分析 之比較して説明したもの ${ }^{129)}$, ケイ酸塩分析の立場から解 
説したもの121) がある.シンポジウムの報告をまとめた ものも引き続き発行された ${ }^{16)}$. 単行本として英訳本が出 版された ${ }^{130)}$. また, 臨床化学における分析法の一分野 として炎光分析を説明したもの131)もある。

$8 \cdot 2 \cdot 2$ 装置 デジタル方式を用いたナトリウムおよ びカリウム定量用の炎光光度計が考案された ${ }^{112)}$. また, 干渉フィルターを用いる炎光光度計でリチウム用フィル ターを用いる内標準法の適用が検討された ${ }^{109) . ~ チ ョ ッ ~}$ パーを用いないで炎の信号を变調する方法として試料を 断続的に噴霧する方法 ${ }^{94)}$, ブランクと標準溶液を交互に 噴霧する方法 ${ }^{95}$ )が研究された. 後者の方法では単光束型 装置で複光束型装置の利点が得られ，マトリックスの影 響が除去できるという．これらの方法は原子吸光分析に 用いると特に利点がある.

炎中への試料導入は炎光分析の感度に影響する. 全 消費式噴霧バーナー（total consumption atomizer burner）を用いた場合の酸水素炎，酸素アセチレン炎 中への試料導入効率を 測定する簡易な方法が 報告され た ${ }^{87)}$. 既知組成, 既知濃度の炎中の亜鉛原子による亜鉛 共鳴線の吸収を測定し, 次式で計算する.

$$
\delta=\frac{A_{\phi}}{A_{\min } \frac{\phi}{\phi_{\min }}}
$$

$\delta$ 注試料導入効率, $A_{\phi}$ 流速 $\phi(\mathrm{m} l / \mathrm{min})$ のとき の吸光度, $A_{\min }$ は流速 $\phi_{\min }(\mathrm{ml} / \mathrm{min})$ のときの吸光 度である。

試料導入効率は試料の流速が増すと減少し, 酸水素炎 で炎の高さとともに増大する.メタノールー水混合物 ではメタノールの濃度が増すにつれて増大する. concentric atomizer では毛細管を通る液体の量は液体 の粘度と表面張力に影響されるが， non-concentric atomizer では表面張力は噴霧速度に影響しない114).

試料溶液取り入れ口の高さの違いによる誤差を除くた わ溶液面を一定に保つ簡単な装置が考案された111).

酸素ーアセチレン炎の場合, 試料噴霧に酸素を用いな いで，アセチレンを用いると炎が安定する ${ }^{88)}$. 発光強度 汇つて理論的研究が行なわれ, 測定した強度は理論的 な積分強度に比例し, 発光線の半值幅には無関係である ことが示された。

$8 \cdot 2 \cdot 3$ 励起機構および干渉 炎光分析における励起 過程が研究され，有機溶媒による発光増大に関係したい ろいろのパラメーターの影響が定量的に研究された ${ }^{89}$ ). ナトリウムとカルシウムの場合には溶媒の急速な蒸発と 炎の温度の上昇により感度増大が起こるが，スズの場
合には化学ルミネッセンスの寄与がある.酸水素炎ある いは酸素ーアセチレン炎では存在が認められないような 元素も, 燃料の割合を多くした酸素ーアセチレン炎, 空 気一水素炎などに試料の炭化水素溶液を噴霧すると, ス ペクトル中にかなり強い線が認められる85).このような 炎は炭素蒸気で飽和されており, 炭素の強い還元力のた めに炎ガス中で遊離原子の存在のための有利な環境がつ くりだされる。

$$
\mathrm{C}+\mathrm{MO} \longrightarrow \mathrm{CO}+\mathrm{M}^{0}
$$

酸水素炎にナフサ溶液を噴霧すると励起が助長される がここような炎中では熱的励起は理論的に $\simeq 5 \mathrm{eV} に$ 限られる. しかし，多くの原子線およびイオン線が 7〜 $9 \mathrm{eV}$ の励起あるいはイオンポテンシャルをもつもので 認められる113). 高エネルギーふく射線の極大発光淡 の低部，内炎の反応層近くで認められるが，その高さは 励起ポテンシャルおよび分子解離エネルギーの減少とと もに低くなる.カルシウムの発光に対する脂肪酸および その塭の影響も検討された ${ }^{124)}$.

炎の温度を測定する式が導かれた ${ }^{116)}$. 酸水素炎では,

$$
T_{\frac{\mathrm{O}_{2}}{\mathrm{H}_{2}}}=\frac{T_{\mathrm{tip}}-c h^{2}}{1+a\left(x^{\delta}\right)+b\left(x^{\delta}\right)^{2}}{ }^{\circ} \mathrm{K}
$$

ここで $T_{\mathrm{tip}}$ は内炎の先端での炎の温度， $x$ 淡に導入 される酸素ガス 1 モルについての溶液のモル数として表 わした試料の流速， $\delta$ は試料導入効率， $h$ は内炎よりの 高さ $(\mathrm{cm}), a, b, c$ 淀数である. 酸素-アセチレン炎 では

$$
\begin{aligned}
T \frac{\mathrm{O}_{2}}{\mathrm{C}_{2} \mathrm{H}_{2}} & =\frac{T_{\mathrm{tip}}-c h^{2}}{1+f \log e\left[1+a\left(x^{\delta}\right)+b\left(x^{\delta}\right)^{2}\right]}{ }^{\circ} \mathrm{K} \\
x & =1.25 \times 10^{3} \frac{\phi_{\mathrm{H}_{2} \mathrm{O}}}{\phi_{\mathrm{O}_{2}}}
\end{aligned}
$$

$\phi_{\mathrm{H}_{2} \mathrm{O}}$ 核試料の流速 $(\mathrm{m} l / \mathrm{min}), \phi_{\mathrm{O}_{2}}$ 注酸素の流速 $(\mathrm{m} l)$ $\min ), f$ は定数である.

酸素-アセチレン炎中のアルカリ土類元素およびアル カリ元素の相互作用の機構が研究された ${ }^{91)}$. 条件が適当 であれば，イオン化しやすい異種元素の電子濃度が被検 元素の基底状態ポプュレーションに対する影響, エネル ギーふく射線の移動の影響, 励起原子との衝突によるエ ネルギー 移動の影響などにより 発光増大を生ずる。ま た，カリウムとナトリウムの相互作用について，ナトリ ウムの存在によるカリウムの発光強度の増加は炎中の電 離平衡の移動により中性原子の増加を招くためであるこ とが定量的に確められた ${ }^{90)}$. 金属キレートの発光に影響 する諸因子について研究され，キレート戍の性質は金属 
の発光に影響しないことが報告された ${ }^{86)}$. ホウ素の発光 はホウ素含量と試料溶液の分子構造あるいは組成に依存 するので, ホウ素化合物を完全にホウ酸にしておく必要 があるという96).

カルシウムの発光に対する III-A 族イオンの影響に ついて研究され, $\mathrm{BO}_{3}{ }^{3-}, \mathrm{Al}^{3+}, \mathrm{Ga}^{3+}$, In- はいずれ もカルシウムの発光強度を減少させるが, 試料溶液をう すめた場合には $\mathrm{BO}_{3}{ }^{3-}$ の影響は減少するに反し, $\mathrm{Al}^{3+}$ の影響は増大することが報告された ${ }^{84) . メ タ ノ ー ル お よ ~}$ びしょ糖の存在は $\mathrm{BO}_{3}{ }^{3-}$ の影響を少なくするが, $\mathrm{Al}^{3+}$ の影響は増大するという. カルシウムの発光に対する $\mathrm{BO}_{3}{ }^{-}, \mathrm{PO}_{4}{ }^{3-}$ と $\mathrm{Al}^{3+}$ の干渉は本質的に異なるもので ある. $\mathrm{Ga}^{3+} お よ ひ ゙ ~ I^{3+}$ の影響は気相における機構で 説明された. 化学的干渉を少なくする方法としてカルシ ウムに対する陰イオンの干渉はグリセリンの使用によ

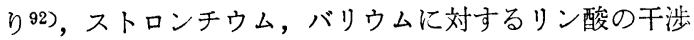
はリン酸 1 モルについて塩化ランタン 5 モルを添加する 方法 ${ }^{93}$ が用いられた. 生体試料中のカルシウムの定量に ついて検討され, カルシウムは励起スペクトルが弱いた めナトリウム, カリウム, リンなど陰陽両イオンの干渉 をうけやすく, ナトリウム $1 \mathrm{mEq} / l$ に対する補正值は $0.018 \mathrm{mEq} / l$ であることが報告された ${ }^{117)}$.

目的元素学錯体として有機溶媒で抽出する方法は干渉 の除去にも役だつ.アルミニウムをアセチルアセトン錯 体として抽出し噴霧する方法97), テルルをジエチルジチ オカルバミン酸錯体として 四塩化炭素で抽出し，四塩 化炭素を蒸発除去後メチルイソブチルケトンを加えて噴 霧測定した報告99)，ホウ素を四ブチルアンモニウムホウ 素-四フッ化物会合体として抽出し定量する報告 ${ }^{126)}$ ， ク ロム定抽出する報告127)，マンガンを TTA 抽出し定量 する報告などがある．目的元素を抽出しないで共存元素 を抽出除去する場合としては，ニッケルーアルミナ触媒 中のニッケルおよびアルミニウムをオキシン錯体として 抽出除去し，ナトリウム，カリウムおよびカルシウムを 定量した報告103)がある。

8.2.4 応用 金属試料への応用としては鋼および銅 合金中のマンガンの定量 ${ }^{102)}$, バックグラウンド補正をし て鉄鋼中のマグネシウム, クロム, 銅, ニッケルおよび コバルトの同時定量 ${ }^{104)}$, イソプロパノールおよびアセト ンの添加してアルミニウム中のリチウムの定量100) など が報告されている。ケイ酸塩関係では耐火物中のアルミ ナの定量 ${ }^{97)}$, ガラス中のカルシウム ${ }^{105)}$, リチウム, ルビ ジウム，セシウム106) の定量などの報告がある. 地球化 学方面では温泉水中のカルシウムの定量 ${ }^{128)}$, 油田地帯 の水の中のセシウムおよびルビジウムをテトラフェニル
ホウ素存在のもとにニトロエタンで抽出して定量する方 法 ${ }^{93)}$, 海水および海生微生物中のカリウムの定量 ${ }^{107)}$, そ の他の方面ではアルカリハライド中の銀の定量 ${ }^{120)}$, 触媒 中のナトリウム，カリウム，カルシウムの定量 ${ }^{103)}$, 有機 ホウ素化合物中のホウ素を試料をアンプル中で硝酸分解 したの方定量する方法 ${ }^{96)}$ などの研究がある. 生化学方 面への炎光分析法の応用として少量の試料 $(0.02 \sim 0.03$ $\mu l)$ を用いて生体液中のナトリウムおよびカリウムを定 量する方法が研究された ${ }^{125)}$. 溶媒としてアセトンを用 い，ふく射線緩衝阂として塩化セシウムおよびリン酸水 素アンモニウムを添加する.

特殊の方法として植物の葉を灰化することなく微粉に し，グリセリン-2-プロパノールに懸濁して噴霧する方 法が報告された101)。

\section{交献}

1) D. A. Long : Chem. Ind., 1963, 7. 2) D. J. David : Spectrochim. Acta, 20, 1185 ('64). 3) R. H. Müller : Anal. Chem., 36(2), 147A ('64). 4) 武者宗一郎, 宗森 信 : 最新の分析化学, 14 集, 55 ('63). 5) 武者宗一郎, 宗森 信: 高分子化学, 12, 685 ('63). 6) 武者宗一郎, 宗森 信: 化学工 場, 8(2), 15 ('64). 7) 武内次夫, 鈴木正巳: 化学 の領域, 18,38('64). 8) 保田和雄, 松平俊次: 分析機器, 1 (8)，47('63). 9) 武内次夫, 鈴木正 巳：“原子吸光分光分析法”，('64)，(南江堂). 10) R. Locker: "Advances in Analytical Chemistry and Instrumentation ", Vol. 3, p. 1 ('64), (Interscience Publishers Inc. New York).

11) P. W. West, A. M. G. Macdonald, T. S. West, ed. : "Analytical Chemistry 1962-The Proceedings of the International Symposium held at Birmingham University, April, 1962", ('63), (Elsevier Publishing Company). 12) A. Walsh : ibid., p. $281 . \quad 13)$ J. H. Gibson. W. E. L. Grossman, W. D. Cooke : ibid., p. 288 . 14) W. T. Elwell, J. A. F. Gidley : ibid., p. $291 . \quad 15)$ R. Locker : ibid., p. $297 . \quad 16)$ J. E. Forrette, E. Lanterman, ed. : "Developments in Applied Spectroscopy', Vol. III, ('64), (Plenum Press, New York). 17) S. R. Koirtyohann, C. Feldman : ibid., p. $180 . \quad 18)$ H. C. Eshelman, J. Armentor : ibid., p. $190 . \quad 19)$ M. E. Doty, W. G. Schrenk : ibid., p. 196.20$)$ J. A. Dean: ibid., p. 207.

21) D. Glick ed. : "Methods of Biochemical Analysis", Vol. 11 ('63), (Interscience Publishers Inc., New York). 22) H. L. Kahn, W. Slavin: Appl. Opt., 2, 931 ('63). 23) W. H. Hinson, R. Kitching : Spectrochim. Acta, 20, 245 ('64). 24) B. G. Davey : ibid., 19, 1319 ('63). 25) 高橋正雄: 分光研究, 12,197 ('64). 26) C. P. Eickhoff, B. J. Sykes : J. Sci. Instr., 41(2), 113 ('64). 27) R. K. Skogerboe, R. A. Woodriff : Anal. Chem., 35, 1977 ('63). 28) R. A. 
Murie, R. C. Bourke : Appl. Spectry., 18, 116 ('64). 29) R. N. Kinseley, A. P. D'silva, V. A. Fassell: Anal. Chem., 35, 910 ('63). 30) K. Fuwa, B. L. Vallee : ibid., 35, 943 ('63).

31) V. G. Mossotti, V. A. Fassell : Spectrochim. Acta, 20, 1117 ('64). 32) V. A. Fassell, V. G. Mossotti : Anal. Chem., 35, 252 ('63). 33) W. Slavin, D. C. Manning : ibid., 35, 253 ('63). 34) W. Lang, R. Herrmann: Mikrochim. Ichnoanal. Acta, 1963, $1053 . \quad 35)$ J. D. Winefordner, C. Veillon: Anal. Chem., 36, 943 ('64). 36) W. Lang, R. Herrmann : Mikrochim. Ichnoanal. Acta, 1963, 872. 37) J. W. Robinson, L. J. Kevan: Anal. Chim. Acta, 28, 170 ('63). 38) R. M. Dagnall, T. S. West : Talanta, 11, 1553 ('64). 39) J. A. Goleb, J. K. Brody : Anal. Chim. Acta, 28, 457 ('63). 40) J. D. Winefordner : Appl. Spectry., 17, 109 ('63).

41) J. D. Winefordner, T. J. Vickers : Anal. Chem., 36, 1947 ('64). 42) L. S. Nelson, N. A. Kuebler : Spectrochim. Acta, 19, 781 ('63). 43) W. Lang, R. Herrmann : Z. Anal. Chem., 199, 161 ('64). 44) L. Erdey, G. Svehla, L. Koetai: Talanta, 10, 531 ('63). 45) D. J. David : Analyst, 89, 747 ('64). 46) F. B. Dowling, C. L. Chakrabarti, G. R. Lyles : Anal. Chim. Acta, 28, 392 ('63). 47) C. L. Chakrabarti, G. R. Lyles, F. B. Dowling : ibid., 29, 489 ('63). 48) M. C. Greaves : Nature, 199, 552 ('63). 49) R. Belcher, R. M. Dagnall, T. S. West : Talanta, 11, 1257 ('64). 50) A. Strasheim, G. J. Wessels: Appl. Spectry., 17, 65 ('63).

51) G. Erinc, R. J. Magee : Anal. Chim. Acta, 31, 197 ('64). 52) J. A. Goleb : Anal. Chem., 35, 1978 ('63). 53) J. A. Goleb, Y. Yokoyama: Anal. Chim. Acta, 30, 213 ('64). 54) L. Wilson: ibid., 30, 377 ('64). 55) F. J. Wallace : Analyst, 88, 259 ('63). 56) K. Kinson, C. B. Belcher: Anal. Chim. Acta, 31, 180 ('64). 57) G. L. Mcpherson, J. W. Price : Nature, 199, 371 ('63). 58) K. Kinson, R. J. Hodges, C. B. Belcher: Anal. Chim. Acta, 29, 134 ('63). 59) 鈴木正巳, 武内次夫 : 工化, 66, 690 ('63). 60) 鈴木正巳, 武 内次夫：同上, 67, 1207 ('64).

61) C. B. Belcher, K. Kinson : Anal. Chim. Acta , 30, 483 ('64). 62) 武内次夫, 鈴木正巳, 道 木英之：工化，66，1194 ('63). 63) K. Kinson, C. B. Belcher : Anal. Chim. Acta, 30, 64 ('64). 64) G. I. Nikolaev, V. B. Aleskovskii : Zh. Analit. Khim., 18, 816 ('63). 65) C. B. Belcher: Anal. Chim. Acta, 29, 340 ('63). 66) J. Perkins : Analyst, 88, 324 ('63). 67) C. B. Belt: Econ. Geol., 59, 240 ('64). 68) I. Rubeška, B. Moldan, I. Valny̌ : Anal. Chim. Acta, 29, 206 ('63). 69) T. Takeuchi, M. Suzuki : Talanta, 11, 1391 ('64). 70) 後藤秀弘, 池田重良, 厚谷郁 夫 : 分化, 13，111 ('64).

71) C. B. Belcher, K. A. Brooks : Anal. Chim. Acta , 29, 202 ('63). 72) 武内次夫, 鈴木武巳 : 工 化, 66, 1541 ('63). 73) 武者宗一郎, 宗森 信,
中西良之：分化，13，330 ('64). 74) K. Fuwa, P. Pulido, R. Mckay, B. L. Vallee : Anal. Chem., 36, 2407 ('64). 75) A. Zettner, D. Seligson: Clin. Chem., 10, 869 ('64). 76) W. K. Stewart, F. Hutchinson, L. W. Fleming : J. Lab. Clin. Med., 61, 858 ('63). 77) C. F. Decker, A. Aras, L. E. Decker : Anal. Biochem., 8, 344 ('64). 78) A. Strasheim, E. Norval, L. R. P. Butler : J. S. Af. Chem. Inst., 17(2), 55 ('64). 79) J. Štupar: $Z$. Anal. Chem., 203, 401 ('64). 80) W. E. C. Wacker, C. Iida, K. Fuwa : Nature, 202, 659 ('64).

81) J. D. Winefordner, T. J. Vickers : Anal. Chem., 36, 161 ('64). 82) J. D. Winefordner, R. A. Staab : ibid., 36, 165 ('64). 83) N. S. Poluektov : "Analytical Chemistry 1962 ”, p. 302 ('63), (Elsevier Publishing Co.). 84) M. E. Doty, W. G. Schrenk : "Developments in Applied Spectroscopy”, Vol. 3, p. 196 ('64), (Plenum Press, New York). 85) J. A. Dean : ibid., p. 207. 86) H. C. Eshelman, J. Armentor : ibid., p. 190. 87) J. D. Winefordner, C. T. Mansfield, T. J. Vickers : Anal. Chem., 35, 1607 ('63). 88) H. F. Loken, J. S. Teal, E. Eisenberg : ibid., 35, 875 ('63). 89) J. H. Gibson, W. E. L. Grossman, W. D. Cooke : ibid., 35, 266 ('63). 90) 安藤 厚, 石田良平 : 分光研究, 12(3), 128 ('64).

91) R. W. Johnson, W. G. Schrenk : Appl. Spectry., 18 (5), 144 ('64). 92) T. C. Rains, H. E. Zitte1, M. Ferguson : Talanta, 10, 367 ('63). 93) J. Yofe, R. Avni, M. Stiller : Anal. Chim. Acta, 28, 331 ('63). 94) R. Herrmann, W. Lang: $Z$. Anal. Chem., 203, 1 ('64). 95) R. Herrmann, W. Lang, K. Rüđiger : ibid., 206, 241 ('64). 96) T. Yoshizaki : Anal. Chem., 35, 2177 ('63). 97) W. Schmidt, K. Konopicky, J. Kostyra : Z. Anal. Chem., 206, 174 ('64). 98) A. G. Collins : Anal. Chem., 35, 1258 ('63). 99) J. A. Dean, J. C. Simms : ibid., 35, 699 ('63). 100) W. E. Pilgrim, W. R. Ford : ibid., 35, 1735 ('63).

101) J. L. Mason : Anal. Chem., 35, 874 ('63). 102) D. A. Johnson, P. F. Lott : ibid., 35, 1705 ('63). 103) E. E. H. Pitt : Analyst, 88, 399 ('63). 104) L. A. Prince, F. V. Coglianese, T. L. Coless: Welding J., 42, 347S ('63). 105) F. Gebhardt, M. Achilles: Glastech. Ber., 36, 225 ('63). 106) F. Hegemann, O. Osterried : ibid., 36, 217 ('63). 107) T. J. Chow : Anal. Chim. Acta, 31, 58 ('64). 108) C. L. Chakrabarti, R. J. Magee, C. L. Wilson: Talanta, 10, 57 ('63). 109）細川 䉷, 本田サトミ, 正木よし子, 羽坂忠義： 分化, 13, 1044 ('64). 110) W. Lang: Mikrochim. Ichnoanal. Acta, 1964, 796.

111) H. Svejda : Mikrochim. Ichnoanal. Acta, 1964, 45. 112) E. A. Boling: J. Lab. Clin. Med., 63, 501 ('64). 113) B. E. Buell : Anal. Chem., 35, 372 ('63). 114) E. Pungor, M. Mahr : Talanta, 10, 537 ('63). 115) E. Preuss, O. Osterried : $Z$. Anal. Chem., 198, 395 ('63). 116) J. D. Winefordner, C. T. Mansfield, T. J. Vicker: Anal. Chem., 35, 1611 ('63). 117) M. Brandstein : Am. J. Clin. Path., 40, 583 ('63). 118) D. 
B. Horn, A. L. Latner : Clin. Chim. Acta, 8, 974 ('63). 119) 高橋正雄, 高島八重子: 分光研究, 13, 14（'64）. 120）福田敦夫, 猪原幸一, 尾中竜猛 : 同 上, 12, 201 ('64).

121) 石井 一：分析機器, 2(4), 54 ('64). 122) 高原喜八郎：同上, $2(11), 11$ ('64). 123) L. R. P. Butler, D. W. Brink: $S$. Af. Ind. Chem., 17 (7), 152 ('64). 124) A. C. West : Anal. Chem., 36, 310 ('64). 125) H. A. Bloomer, D. D. Trammell, F. C. Rector, Jr. : J. Lab. Clin. Med., 61, 692 ('63). 126) W. J. Maek, M. E. Kussy, B. E.
Ginther, G. V. Wheeler, J. E. Rein : Anal. Chem., 35, 62 ('63). 127) J. R. Daly, H. B. Anstall: Clin. Chim. Acta, 9, 576 ('64). 128) J. J. Rowe: Geochim. Cosmochim. Acta, 27, 915 ('63). 129) 長谷川敬彦 : 綜合臨床, 13, 1048 ('64). 130) R. Herrmann, C. T. J. Alkemade (translated by P. T. Gilbert, Jr.) : "Chemical Analysis by Flame Photometry ", ('63), (Wiley, New York).

131) R. J. Henry " Clinical Chemistry, Principles and Techniques ", ('64), (Harper and Row, New York).

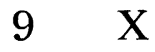

線

高 木

前回の総説に引き続き，1962１964 における X 線分 析は各種の工業界で応用開発され，それぞれの目的に応 じた機器の改良が加えられた。特にケイ光 X線分析は工 業管理分析部門において発光分光分析と肩を並べるまで に発展してきた。国内におけるX線分析も各地における 日本分析化学会主催の講習会での紹介コース，X線工業 分析研究㼟談会の月例会などで X 線分析への認識を高 內, 機器の設置台数の増加とともに急速に普及してき た. 管理分析部門でも管理分析用として輸入された外国 機器, あるいは国内産機器もそれぞれ設置された工場で その特徵を生かして真価を発揮していると聞いている。 国産X線マイクロアナライザーも日立製作所に続いて数 社において国産化に成功したが，これら機器による金属 組織中の微偏析など本機器のもつ特徽を生かした新しい 解析発表が鉱工業，合金材料などの部門でみられるもの と期待している.

\section{$9 \cdot 1$ ケイ光X線分析法}

ケイ光 $\mathrm{X}$ 線分析は分析法の特徵の諗識と機器の普及に 乞もない解説, 総説的な報文は国内学会誌のX 線特集号 あるい注特別講座, 応用分野の各団体の分析講習会のテ キストなどに数多く発表されている1) 12).

分析装置の改良, 開発面では機器全体の電気回路の安 定化のための改良は別として, 試料面からの二次 X 線 （分析線）の強度を強めるための改良は励起線源の励起 電圧の上昇, 試料と励起線源間の距離の短縮, 二次 $\mathrm{X}$ 線

* 東洋曹達工業株式会社研究部 (山口県南陽町富田)
の吸収, 散乱防止のための真空装置, 湾曲分光結晶の使 用, 検出器の空材料のくふうなどがなされている. 軽元 素のケイ光 $\mathrm{X}$ 線分析においてクロムターゲットを使用 し, ヘリウムパスの分光系で検知器のガスフローカウン ターの空材料を薄く改良して $1 \%$ 付近のナトリウム, 有機化合物中の塩素, アルミニウムの低濃度の測定を行

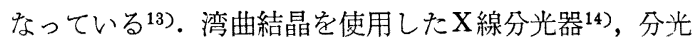
装置のギヤーをローラー伝達に置き替えた装置15)，励起 線源の泠却水を蒸留水を使用して多段熱交換器を使用し

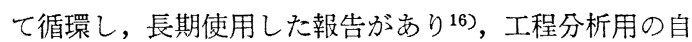
動ケイ光 $\mathrm{X}$ 線分析装置の装置解説 17 および応用報告があ る18) 20).

ケイ光X線装置においてそれぞれの装置定数ならびこ

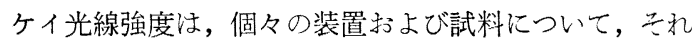
ぞれ検討されなければならないが，モリブデンおよびタ ングステン管を使用した場合の各元素のケイ光 $\mathrm{X}$ 線強度 の測定結果が発表されている21)。 また励起 X 線とケイ 光 $\mathrm{X}$ 線の入射角および反射角がケイ光 $\mathrm{X}$ 線に及ぼす効 果 ${ }^{22)}$, 低濃度の対象試料を検出する場合の装置定数度ら びにメリット指数について検討した報告がある23).

ケイ光 $\mathrm{X}$ 線分析では試料の状態および共存元素恃分析 線の強度に大きく影響し, 日常分析において本分析法を 採用した場合に，分析精度を高め微量分析に応用与るた めには試料の処理法が最大の要因となる. 共存元素の影 響を小さくするとか，あるいはあらかじめ測定值の補正 項を計算しておく必要がある.ケイ光 $\mathrm{X}$ 線分析の場合, 機器装置の改良面を除けば研究の大半はこの試料処理と 